\title{
Morbidity profile and its determinants among the elderly residing in rural field practice area of Shirur, rural health training centre, Bagalkot-North Karnataka-a cross-sectional study
}

\author{
Sachin V. Desai ${ }^{1{ }^{* *}, \text { Kshitij Arora }}{ }^{2}$, Ashok S. Dorle ${ }^{3}$, Manjula. $\mathbf{R}^{4}$ \\ ${ }^{1}$ Assistant Professor, ${ }^{2}$ Intern, ${ }^{3}$ Professor \& Head, ${ }^{4}$ Associate Professor, Dept. of Community Medicine, S.N Medical College, \\ Bagalkot, Karnataka, India
}

*Corresponding Author:

Email: desai.v.sachin@gmail.com

\begin{abstract}
Introduction: "Old age is an incurable disease" as said by Seneca. As Sir James Sterling Ross commented, "You cannot heal old age. You protect it; you promote; you extend it". Scientific advances have increased the life span of man. The life expectancy at birth is estimated to be 67.6 in men and 70.1 years in women in developing countries, increasing the number of old age people in the society. Aged elderly, have a number of health problems and the assessment of the problems is of utmost importance and the need of the hour.

Materials and Methods: It was a cross sectional study done in field practice area of Department of Community Medicine, S.N. Medical college, Bagalkot for a duration of four months on 274 elderly participants. Data was collected using a predesigned pretested pro-forma. Morbidity pattern was assessed by clinical examination and appropriate assessment tools.

Results: Majority were young old elderly, with very low levels of literacy, belonging to class IV socioeconomic class. $32.1 \%$ were unemployed, $43.4 \%$ were Below Poverty Line. Joint families were predominant among the study population i.e. $66.8 \%$. Majority of the elderly i.e. $94.9 \%$ were living with their families. Generalized weakness, joint pain, loss of appetite were the predominant complaints beginning in the young old i.e. in 60-74years. Diabetes, Hypertension, Upper GI system morbidities, ophthalmic morbidities and Hearing impairment were very common in the old age group (75-89years).

Conclusion: The young old elderly suffered from constitutional symptoms, and the old elderly suffered from non-communicable diseases.
\end{abstract}

Keywords: Morbidity profile, Determinants, Elderly, Rural area.

\section{Introduction}

Ageing is a natural process and everyone ages from the day of conception. In India, $8.5 \%{ }^{1}$ of total population is above the age of 60years in 2015. It is expected to touch $17 \%$ mark by $2050 .{ }^{2}$ The discoveries in medical sciences and improved social conditions during the past decades have increased the life span of man to 67.6 years in men and 70.1 in women. ${ }^{3}$ This leads to continuous increase in the number of elderly in the society. Hence the current study was done to know the prevalence of Geriatric Morbidities among rural elderly \& the determinants which influence the morbidity profile of these rural elderly.

\section{Materials and Methods}

It was a community based cross-sectional study in rural field practice area of Department of community medicine, S. N. Medical College, Bagalkot for a period of four months from June 2016 to October 2016. Elderly above 60 years residing for more than one year in the study area, were included in the study. Deaf, dumb, visually impaired elderly with psychiatric morbidities were excluded from the study.

Sample size calculation done using Open Epi Software $2.3 .1^{3}$ At $95 \%$ confidence level; According to the study conducted, 'Prevalence of Musculoskeletal Disorder (Ashok Kumar T) ${ }^{4}$ in elderly'-23.6=P At 5\% absolute precision, sample size calculated is 274 .
Ethical clearance has been obtained from the Institutional Ethical Committee.

As per the Community Need Assessment (CNA) ${ }^{5}$ survey, demographic details of the elderly population residing in Shirur, RHTC was demarcated. Using simple random sampling technique with the help of a computer generated random number table, elderly coming under the inclusion criteria were selected from the study area till the sample was completed. Written informed consent of the selected subjects was taken. Using predesigned pretested questionnaire socio-demographic details were collected. Clinical examination was done. Anaemia was diagnosed by clinical examination of nails and conjunctiva mucosa. Blood pressure was measured using mercury sphygmomanometer in supine position. Vision was assessed using Snellen's chart. ${ }^{6}$ Vision less than $6 / 60$ to counting fingers up to $1 / 2$ meters was further evaluated for cataract changes in the lens. Elderly with history of joint pain, swelling and restriction of movements were considered to have osteoarthritis. Obesity was assessed by calculating Body Mass Index $(\mathrm{BMI})^{7}$ (Weight in $\mathrm{kg} / \mathrm{height}$ in metre ${ }^{2}$ ). BMI more than 25 were classified as overweight. Presence of basal crepitation and chronic cough were considered to have respiratory pathology. Relevant Past and Personal history was assessed to find out the factors affecting the current morbidity status. The morbidities were classified 
as per the international classification of diseases $11^{\text {th }}$ revision. ${ }^{8}$

\section{Results}

Majority of the elderly were males, belonging to young old age group (60-74 years) ${ }^{9}$ with literacy levels up to primary school among $23.1 \%$. With increasing age the number of unemployed elderly were more. $43.4 \%$ were below poverty line. ${ }^{10}$ Joint families were predominant among the study population i.e. $66.8 \%$. Majority of the elderly i.e. $94.9 \%$ of the elderly were living with their families. Generalized weakness $181(66.1 \%)$, joint pain $184(67.1 \%)$, loss of appetite $113(41.2 \%)$ were the predominant complaints as described by the elderly, beginning in the young old (6074 years). Common in the old age group (75-89years) were the following morbidities: gastrointestinal problems $(32.7 \%)$ followed by cardiovascular problems $(27.3 \%)$, Respiratory problems $(22.2 \%)$, and Central nervous system problems (17.5\%) and $17.5 \%$ were diabetic patients as identified by the researcher by clinical examination. None of the elderly underwent any biochemical tests.

Table 1: Socio demographic details of study participants.

\begin{tabular}{|c|c|c|c|c|c|c|}
\hline $\begin{array}{c}\text { Socio } \\
\text { Demographic } \\
\text { Variables } \\
\end{array}$ & \multicolumn{2}{|c|}{ Males(n=159) } & \multicolumn{2}{|c|}{ Females $(n=115)$} & $\begin{array}{c}\text { Total }(\%) \\
(n=274)\end{array}$ & \\
\hline AGE(yrs.) & No. & $\%$ & No. & $\%$ & & \multirow{3}{*}{$\begin{array}{l}\chi^{2}=2.343 \\
p=0.126\end{array}$} \\
\hline $\begin{array}{l}\text { 60-74 } \\
\text { (Young-old) }\end{array}$ & 132 & 48.1 & 103 & 37.5 & $235(85.6)$ & \\
\hline $\begin{array}{l}75-89 \\
\text { (Old-old) }\end{array}$ & 27 & 9.8 & 12 & 4.3 & $39(14.4)$ & \\
\hline \multicolumn{7}{|l|}{ Education } \\
\hline Illiterate & 67 & 24.4 & 89 & 32.4 & $156(56.9)$ & \multirow{7}{*}{$\begin{array}{l}\chi^{2}=5.937 \\
p=0.430\end{array}$} \\
\hline Primary & 43 & 15.6 & 20 & 7 & $63(22.9)$ & \\
\hline High school & 33 & 12 & 4 & 1 & $37(13.5)$ & \\
\hline PUC & 3 & 1 & 2 & 1 & $5(1.8)$ & \\
\hline Diploma & 3 & 1 & 0 & 0 & $3(1)$ & \\
\hline Graduate & 2 & 1 & 0 & 0 & $2(1)$ & \\
\hline Post-graduate & 8 & 2.91 & 0 & 0 & $8(2.9)$ & \\
\hline \multicolumn{7}{|l|}{$\begin{array}{l}\text { Socioeconomic status } \\
\text { (Modified BG Prasad } \\
\text { Classification.) }\end{array}$} \\
\hline Class 1 & 10 & 3.64 & 4 & 1.45 & $14(5.09)$ & \multirow{5}{*}{$\begin{array}{l}\chi^{2}=0.819 \\
p=0.936\end{array}$} \\
\hline Class 2 & 17 & 6.20 & 14 & 5.10 & $31(11.3)$ & \\
\hline Class 3 & 46 & 16.78 & 29 & 10.58 & $75(27.36)$ & \\
\hline Class 4 & 58 & 21.16 & 42 & 15.32 & $100(36.48)$ & \\
\hline Class 5 & 28 & 10.21 & 28 & 10.21 & $56(20.42)$ & \\
\hline \multicolumn{7}{|l|}{ Past morbidity } \\
\hline Diabetes & 31 & 11.31 & 17 & 6.20 & $48(17.5)$ & $\begin{array}{l}\chi^{2}=0.282 \\
p=0.595\end{array}$ \\
\hline Hypertension & 29 & 10.58 & 18 & 6.30 & $47(16.88)$ & $\begin{array}{l}\chi^{2}=1.123 \\
p=0.289\end{array}$ \\
\hline Depression & 9 & 3.28 & 6 & 2.18 & $15(5.46)$ & $\begin{array}{c}\chi^{2}=8.630 \\
\mathrm{p}=0.03^{*} \\
\text { (statistically } \\
\text { significant) }\end{array}$ \\
\hline Past surgeries & 67 & 24.45 & 49 & 17.88 & $116(42.33)$ & $\begin{array}{l}\chi^{2}=0.017 \\
p=0.897\end{array}$ \\
\hline Malabsorption & 4 & 1.45 & 2 & 1 & $6(2.45)$ & $\begin{array}{c}\chi^{2}=23.993 \\
\mathrm{p}=0.000 * \\
\text { (statistically } \\
\text { significant) }\end{array}$ \\
\hline Asthmatic attacks & 18 & 6.56 & 14 & 5.10 & $32(11.66)$ & $\begin{array}{l}\chi^{2}=3.340 \\
p=0.064\end{array}$ \\
\hline Past illness & 4 & 1.45 & 4 & 1.45 & $8(2.9)$ & $\begin{array}{l}\chi^{2}=0.782 \\
p=0.376\end{array}$ \\
\hline Blood transfusion & 6 & 2.18 & 3 & 1 & $9(3.18)$ & $\begin{array}{l}\chi^{2}=1.544 \\
p=0.214\end{array}$ \\
\hline Previous hospitalization & 28 & 10.21 & 19 & 6.93 & $47(17.14)$ & $\chi^{2}=2.864$ \\
\hline
\end{tabular}




\begin{tabular}{|c|c|c|c|c|c|c|}
\hline & & & & & & $\mathrm{p}=0.091$ \\
\hline Nil Morbidity & 48 & 17.5 & 47 & 17.3 & $95(34.8)$ & \\
\hline \multicolumn{7}{|l|}{ Marital status } \\
\hline Unmarried & 1 & 0.5 & 3 & 1 & $4(1.5)$ & \multirow{3}{*}{$\begin{array}{c}\chi^{2}=6.958 \\
p=0.31\end{array}$} \\
\hline Married & 136 & 49.6 & 85 & 31.02 & $221(80.62)$ & \\
\hline Widow/widower & 22 & 8.02 & 29 & 10.5 & $51(18.52)$ & \\
\hline Divorcee & - & - & - & - & - & \\
\hline \multicolumn{7}{|l|}{ Type of family } \\
\hline Joint & 100 & 36.49 & 84 & 30.8 & $184(67.29)$ & \multirow{4}{*}{$\begin{array}{c}\chi^{2}=2.490 \\
p=0.477\end{array}$} \\
\hline Nuclear & 54 & 19.70 & 30 & 10.94 & 84() & \\
\hline Broken & 3 & 1 & 3 & 1 & $6(2)$ & \\
\hline Problem & 2 & 1 & 0 & 0 & $2(1)$ & \\
\hline \multicolumn{7}{|l|}{ Living with family } \\
\hline Yes & 151 & 55.10 & 111 & 40.51 & $262(95.61)$ & \multirow{2}{*}{$\begin{array}{l}\chi^{2}=1.031 \\
p=0.597\end{array}$} \\
\hline No & 8 & 2.91 & 6 & 2.18 & $14(5.09)$ & \\
\hline \multicolumn{7}{|l|}{ Type of diet } \\
\hline Veg & 50 & 18.24 & 42 & 15.32 & $92(33.96)$ & \multirow{2}{*}{$\begin{array}{c}\chi^{2}=10.332 \\
\mathrm{p}=0.006^{*} \\
\text { (statistically } \\
\text { significant) }\end{array}$} \\
\hline Mixed & 105 & 38.32 & 76 & 27.73 & $181(66.05)$ & \\
\hline \multicolumn{7}{|l|}{ Habits } \\
\hline Smoking & 80 & 29.19 & 15 & 5.47 & $95(34.66)$ & $\begin{array}{c}\chi^{2}=11.917 \\
\mathrm{p}=0.003^{*} \\
\text { (statistically } \\
\text { significant) }\end{array}$ \\
\hline Tobacco chewing & 76 & 27.73 & 48 & 17.5 & $124(45.23)$ & $\begin{array}{c}\chi^{2}=13.115 \\
\mathrm{p}=0.001^{*} \\
\text { (statistically } \\
\text { significant) }\end{array}$ \\
\hline Neither & 3 & 1 & 52 & 18.97 & 54(19.97) & \\
\hline \multicolumn{7}{|l|}{ Family history } \\
\hline Diabetes & 11 & 4.01 & 5 & 1.82 & $16(5.83)$ & $\begin{array}{l}\chi^{2}=0.887 \\
p=0.346\end{array}$ \\
\hline Hypertension & 7 & 2.55 & 1 & 0.5 & $8(3.05)$ & $\begin{array}{c}\chi^{2}=0.020 \\
\mathrm{p}=0.887\end{array}$ \\
\hline Dementia & 1 & 0.5 & 0 & 0 & $1(0.5)$ & $\begin{array}{c}\text { Fishers exact } \\
\mathrm{p}=1.000\end{array}$ \\
\hline Asthma & 13 & 4.74 & 3 & 1 & $16(5.74)$ & $\begin{array}{c}\chi^{2}=0.887 \\
p=0.346\end{array}$ \\
\hline Cancer & 1 & 0.5 & 0 & 0 & $1(0.5)$ & $\begin{array}{c}\text { Fishers exact } \\
\mathrm{p}=1.000\end{array}$ \\
\hline Depression & 2 & 1 & 0 & 0 & $2(1)$ & $\begin{array}{c}\text { Fishers exact } \\
\mathrm{p}=1.000\end{array}$ \\
\hline \multicolumn{7}{|l|}{ Oral hygiene } \\
\hline Good & 94 & 34.3 & 80 & 29.19 & $174(63.49)$ & \\
\hline Poor & 65 & 23.72 & 37 & 13.5 & $102(37.22)$ & \multirow{10}{*}{$\begin{array}{c}\chi^{2}=1.889 \\
p=0.169\end{array}$} \\
\hline Body mass index & & & & & & \\
\hline $\begin{array}{l}<18.5 \mathrm{~kg} / \mathrm{m} 2 \\
\text { Underweight }\end{array}$ & 33 & 12 & 28 & 10.2 & $61(22.2)$ & \\
\hline $\begin{array}{l}18.5-22.9 \mathrm{~kg} / \mathrm{m} 2 \\
\text { Normal }\end{array}$ & 83 & 30.2 & 65 & 23.7 & $148(53.9)$ & \\
\hline $\begin{array}{l}23-24.9 \mathrm{~kg} / \mathrm{m} 2 \\
\text { Overweight } \\
\end{array}$ & 24 & 8.7 & 9 & 3.2 & $33(11.9)$ & \\
\hline $\begin{array}{l}25-29.9 \mathrm{~kg} / \mathrm{m} 2 \\
\text { Pre-obese }\end{array}$ & 6 & 2.1 & 7 & 2.5 & $13(4.6)$ & \\
\hline \multicolumn{6}{|l|}{ Obese (=>30) } & \\
\hline $\begin{array}{l}30-40 \mathrm{~kg} / \mathrm{m} 2 \\
\text { Obese }\end{array}$ & 7 & 2.5 & 6 & 2.2 & $13(4.7)$ & \\
\hline $\begin{array}{l}40.1-50 \mathrm{~kg} / \mathrm{m} 2 \\
\text { Morbid obese }\end{array}$ & 3 & 1 & 2 & 1 & $5(2)$ & \\
\hline$>50 \mathrm{~kg} / \mathrm{m} 2$ & 1 & - & 0 & - & $1(0.7)$ & \\
\hline
\end{tabular}




\begin{tabular}{|c|c|c|c|c|c|c|}
\hline Super obese & & & & & & \\
\hline $\begin{array}{l}\text { Mid upper arm } \\
\text { circumference }\end{array}$ & & & & & & \multirow{3}{*}{$\begin{array}{c}\chi^{2}=36.803 \\
\mathrm{p}=0.001 * \\
\text { (Statistically } \\
\text { significant). }\end{array}$} \\
\hline$<24 \mathrm{cms}$ & 87 & 31.7 & 71 & 25.9 & $158(57.6)$ & \\
\hline$>24 \mathrm{cms}$ & 72 & 26.4 & 44 & 16 & $116(42.4)$ & \\
\hline \multicolumn{7}{|l|}{ Waist-hip ratio } \\
\hline $\begin{array}{l}<0.95 \text { for } m e n / 0.85 \text { for } \\
\text { women }\end{array}$ & 157 & 57.2 & 100 & 36.4 & $257(93.6)$ & \multirow[t]{2}{*}{$\begin{array}{l}\chi^{2}=1.012 \\
p=0.315\end{array}$} \\
\hline $\begin{array}{l}>0.95 \text { for } m e n / 0.85 \text { for } \\
\text { women }\end{array}$ & 2 & - & 15 & 5.4 & $17(5.4)$ & \\
\hline
\end{tabular}

$\chi^{2}=$ chi square $*=$ statistically significant

Table 2: Morbidity profile of the elderly participants.

\begin{tabular}{|l|c|c|c|}
\hline Morbidity profile of the elderly participants & Gender & & $\begin{array}{c}\text { ICD-11 } \\
\text { CODING }\end{array}$ \\
\hline Organ system involved & & & \\
\hline & $\begin{array}{c}\text { Male } \\
\text { (no.) }\end{array}$ & $\begin{array}{c}\text { Female } \\
\text { (no.) }\end{array}$ & Code \\
\hline Nervous system & 24 & 9 & 8 A00.0Z \\
\hline Parkinson's disease & 13 & 2 & \\
\hline Tremor & 2 & 0 & \\
\hline Small handwriting & 15 & 7 & \\
\hline Stooping gait & 8 & 1 & \\
\hline Constipation & 14 & 1 & \\
\hline Soft/low voice & 6 & 0 & \\
\hline Loss of smell & 14 & 6 & \\
\hline Trouble sleeping & 12 & 2 & \\
\hline Trouble swallowing & 4 & 0 & \\
\hline Masked face & 14 & 6 & \\
\hline Trouble sleeping & & & \\
\hline Cardiovascular system & 28 & 17 & BA00.Z \\
\hline Hypertension & 112 & 82 & MC16 \\
\hline Pallor (Conjunctiva) & 7 & 7 & EE10.0 \\
\hline Clubbing (Digital clubbing) & & & \\
\hline Respiratory system & 70 & 29 & MD12 \\
\hline Cough & 77 & 30 & MD11.5 \\
\hline Breathlessness (Dyspnoea) & & & \\
\hline Gastrointestinal system & 25 & 13 & MD90.1 \\
\hline Vomiting & 45 & 26 & DA41.2 \\
\hline Acid Hypersecretion. & 24 & 13 & MD93 \\
\hline Dysphagia & 21 & 13 & MD90.1 \\
\hline Food Regurgitation (vomiting) & 16 & 10 & ME05.1 \\
\hline Diarrhoea & 26 & 12 & ME05.0 \\
\hline Constipation & 2 & 3 & ME24.A4 \\
\hline Blood in stools & 31 & 23 & MD81.1Z \\
\hline Localised Abdominal pain (unspecified) & & & \\
\hline & & & \\
\hline
\end{tabular}

\section{Discussion}

The present community based study in rural field practice area of Shiv Ganga Rural Health Training Centre, Shirur, with a sample size of 274 revealed a moderate prevalence of morbidity $65.4 \%$.

A study carried out in Southern part of India reported a similar result that is a prevalence of $82.9 \%$ in the age group of 60 years and above ${ }^{11}$. In our study, majority were male elderly population, coinciding with the Munshi et al. ${ }^{12}$
Findings with $(42 \%)$ being women and rest being men. Since our study was carried out in the most rural of Karnataka, more than half $(56.9 \%)$ of the elderly were illiterate, followed by primary school (22.9\%), high school $13.5 \%$, Pre-University College $(1.8 \%)$, graduate and above (3.9\%). The findings were very similar to Kamble SV's Verma V, Ghosh A, Srinivas PJ ${ }^{13-16}$ studies revealing the illiterate population to be higher $(59.86 \%)$. Health is intimately linked with the level of literacy since literacy enables greater awareness about their health needs, utilization of health-care services, and 
appropriate intake of medications. Most of the elderly are living with their spouse, i.e. (80.62\%), widows were $(8.02 \%)$ and widowers were $(10.5 \%)$. Majority of the families $(67.29 \%)$, were living in joint families and (20.42\%) belonged to class II \&below, only (5.09\%) were of class I socio-economic status as per modified BG Prasad scale May 2015 AIPCI 273. The 52nd round of NSSO also showcased a similar picture of the poor situation of the elderly in India. ${ }^{17}$ The average number of morbidity per person in our study was calculated to be 3.37 , with only few $(34 \%)$ of them being free from any form of morbidities. These findings are similar to the study done by Purty et $\mathrm{al}^{18}$ in the rural areas of Tamil Nadu, where the average number was recorded as 2.77and Swami et a ${ }^{19}$ reported 3.28 among the elderly in Chandigarh. The findings also find similarity in the Kashmir study by Parray et al, ${ }^{20}$ where there was a total of 632 morbidities and the average number of illness per person was calculated to be 3.28 . It was also observed that in our study, there was a total of 924 morbidities (multiple morbidities) among the 274 elderlies, with males contributing to majority $(66.2 \%)$ of the total morbidities. The most common morbidities suffered by the elderly in this study were gastrointestinal problems $(32.7 \%)$. This was followed by cardiovascular problems (27.3\%), respiratory problems $(22.2 \%)$, and Central nervous system problems (17.5\%). Only (16.88\%) of them were hypertensive and $(17.5 \%)$ were diabetic. $11.67 \%$ of the elderly gave history of asthmatic attacks. Our study did not find any association between gender, level of education, occupation, and morbidity pattern of the elderly. This is found to be similar to George LS et al findings. ${ }^{21}$ In current study, majority of the study population doesn't know about family history of some chronic diseases, whereas those having family history, diabetes was the commonest $(5.83 \%)$, followed by asthma $(5.74 \%)$, which was similar to Srinivas $\mathrm{PJ}^{16}$ who found most common history of previous illness was hypertension $12 \%$ and diabetes mellitus $6 \%$ in both rural and urban areas. Present study showed that tobacco chewing $(45.23 \%)$ as the commonest form of addiction, while (34.66\%) are addicted to smoking. George et al, ${ }^{21}$ study showed that smoking tobacco in $(31.2 \%)$ as the commonest form of addiction, while (13.8\%) use nonsmoke tobacco (chewable form such as khaini, gutkha etc.) and $(12.7 \%)$ addicted to alcohol in their study. Regarding morbidity profile, we observed that joint pain was the commonest $(67.1 \%)$ morbidity followed by generalized weakness $(66 \%)$. Persons suffering from nutritional Anaemia (74.8\%) found in present study was higher $(40 \%)$ than Srinivas PJ, Kumar R, Mundada V, Hameed S. ${ }^{16,22-24}$ studies. Impaired vision $(22.2 \%)$ found in present study was almost similar to lower prevalence $(24.2 \%, 27 \%$ and $31.32 \%)$ respectively of impaired vision shown by Kumar R, Srinivas PJ and Ghosh A. ${ }^{16,22,24}$ Impaired hearing (21.5\%) in current study was almost similar $(24.8 \%)$ to Mundada $\mathrm{V}$ study. ${ }^{23}$ Hypertension (3.05\%) was much less than that of
Mundada V, Kamble SV, Rafiq M and Karmakar N et al. ${ }^{23,13,25-26}$ Much higher prevalence was seen in Kumar $\mathrm{R}$ and Hameed S.22,24 Diabetes mellitus $(5.83 \%)$ in present study was similar (4\% and 5.9\%) respectively to findings by Kamble SV, Srinivas PJ. ${ }^{13,16}$ Higher (12.7\%, $19.7 \%$, and $32.3 \%$ ) respectively, diabetes was shown by Kumar R, Hameed S and Rafiq M. ${ }^{22,24,25}$

\section{Conclusions}

Generalized weakness, joint pain, loss of appetite were the predominant complaints beginning in the young old (60-74 years). Diabetes, hypertension, Upper GI system morbidities, ophthalmic morbidities and hearing impairment were very common in the old age group (7589 years).

\section{Recommendations}

Regular screening of all elderly at the rural health training centres, primary health centres and urban health centres. Establishing preventive geriatric clinics at these health centres. Rehabilitation to the elderly who have suffered disabilities due to these morbidities. Self-care awareness programmes for the elderly regarding healthy lifestyle for graceful ageing.

Acknowledgements: To all the study participants.

\section{Conflict of Interests: None.}

Funding for the Study: None.

Limitations of the Study: No biochemical tests were done to detect specific morbidities.

\section{References}

1. Wan He, Daniel Goodkind, Paul Kowal, An ageing world 2015, [online]. March 2016 [Cited on 2018 July 05]; Available from URL: http://www.nih.gov/newsevents/news-releases/worlds-older-population-growsdramatically.pdf

2. India life expectancy at birth 2017[Online] March 2017[Cited on 2018 July 05]; Available from URL: http://www.Indexmundi.com/India/life_expectancy_at_bi rth.html

3. Open Source Epidemiological Statistics for Public Health version 3.01 April 2013[Cited on 2018 July 05]; Available from

URL:http://www.openepi.com/Menu/OE_Menu.htm

4. Kumar, A. T., K. R. Sowmiya, and G. Radhika. "Morbidity pattern among the elderly people living in a Southern Rural India-A cross sectional study." Nat J Res om Med. 1.1 2012:15-9.

5. Community Need Assessment. Atlanta, GA: Centres of Disease control and prevention (CDC), 2013[Cited on 2018 July 05]; Available from URL: https://www.cdc.gov/globalhealth/healthprotection /fetp/training_modules/15/communityneeds_pw_final_9252013.pdf.

6. Snellen eye test chart interpretation March 2018[Cited on 2018 July 05]; Available from URL:https://www.precision-vision.com/snellen-eye-testcharts-interpretation.html 
7. Appropriate body-mass index for Asian populations and its implications for policy and intervention strategies [Online]. [Cited 2018 July 5] THE LANCET Volume 363, No. 9403, p157-163, Available from: URL: http://dx.doi.org/10.1016/S0140-6736(03)15268-3.

8. ICD-11Mortality and Morbidity statistics[Online].Cited on 2018 August 13];Available from URL: https://icd.who.int/devct11/icd11_mms/en/current\#/

9. Definition of Young old March 2018[Cited on 2018 July 05]; Available from: https://medicaldictionary.thefreedictionary.com/youngold.htm.

10. B G Prasad's socioeconomic scales for 2018 [Online]. [2018 July 5] Available from: URL: http://prasadscaleupdate.weebly.com

11. Definition of an older or elderly person. April 2018[Cited on 2018 July 05];Available from URL: http://www.who.int/healthinfo/survey/ageingdefnolder/en/.html

12. Munshi YI, Iqbal M, Rafique H, Ahmad Z. Geriatric morbidity pattern and depression in relation to family support in aged population of Kashmir valley. Internet $J$ Geriatr Gerantol 2008; 4:18- 22.

13. Kamble SV, Ghodke YD, Dhumale GB, Avchat SS, Goyal RC. Health Status of Elderly Persons in Rural Area of India. Indian Medical Gazette-August. 2012:295-99

14. Verma V, Prakash S, Parveen K, Shaikh S, Mishra N. A comparative study of morbidity pattern in elderly of rural and urban areas of Allahabad district, Uttar Pradesh, India. Int J Com Med Public Heal. 2016;3(5):1152-6.

15. Ghosh A, Sarkar D, Pal R, Mukherjee B. A Profile of Common Morbidities among Elderly Rural Indian Population. Am J Pub Heal Res. 2015;3(5A):29-33.

16. Srinivas PJ, Manjubhashini S. A Study on Morbidity Profile among Elderly Population in Visakhapatnam District, Andhra Pradesh. (IOSR-JDMS). 2014;13(9):2125.

17. Government of India. National Sample Survey - 52nd Round. Morbidity and Treatment of Ailments. July 1995- June 1996; Report No. 441. Last accessed on [2016 Aug 8]. Available from URL: http://www.mahades. maharashtra.gov. in/display RepForCat.do? rep CatId = NSS

18. Purty AJ, Bazroy J, Kar M, Vasudevan K, Veliath A, Purushottam P. Morbidity pattern among the elderly population in the rural area of Tamil Nadu, India. Turk $J$ Med Sci. 2006;36:4550.

19. Swami HM, Bhatia V, Dutt R, Bhatia SP. A community based study of the morbidity profile among the elderly in Chandigarh, India. Bahrain Med Bull 2002; 24:13 - 6.

20. Parray SH, Ahmed D, Ahmed M, Gaash B. Morbidity profile of geriatric population in Kashmir, India. Indian $J$ Pract Doct. 2008;4:1-2.

21. George LS, Deshpande S, Krishna Kumar MK, Patil RS. Morbidity pattern and its sociodemographic determinants among elderly population of Raichur district, Karnataka, India. J Family Med Prim Care. 2017;6:340-4.

22. Kumar R, Bahal SP, Srivastava A. Morbidity pattern of geriatric population in rural areas of western Uttar Pradesh. Inter J Medic Sci and Pub Heal. 2016;5(3):43033.

23. Mundada V, Jadhav V, Gaikwad AV. Study of addiction problems and morbidity among geriatric population in rural area of Aurangabad district. J Midlife Health. 2013;4(3):172-5.

24. Hameed S, Kumar N, Naik PM, Sachidananda K, Prasanna KS. Morbidity Pattern among the Elderly
Population in A Rural Area of Dakshina Kannada, Karnataka-A Cross Sectional Study. Nat J Com Medic. 2015;6(2):222-25.

25. Rafiq M, Yasmeen, Ashfaq, Shalinder, Rifat. Health Problems of the Elderly in Budgam District (J\&K): A Cross Sectional Study. Inter J Contemporary Medic Res. 2016;3(12):3456-58.

26. Karmakar N, Nag K, Datta A, Datta SS, Bhattacharjee P. A cross-sectional study on morbidity pattern of elderly population residing in a rural area of Tripura. Int $J$ Res Med Sci 2017; 5:5030-5. 